\title{
The Effect of Micromachining Process to the Biocompatibility of 3C-SiC Membranes
}

\author{
N.F. Mohd Nasir, E. Gan, R. Shukla, T.Istivan, E. Pirogova, P. Tanner and A.S. Holland
}

\begin{abstract}
C-Silicon Carbide (SiC) has been identified as a potential biomaterial for implantable devices. The prospect of 3C-SiC membrane as the working component for BioMEMS in in-vitro blood pressure sensing could be a new challenge for biomedical engineers. Although, $3 \mathrm{C}-\mathrm{SiC}$ is known to be biocompatible, but the micromachining process normally used in semiconductor industry might alter the biocompatibility of 3C-SiC. In this study, we investigate the biocompatibility of $3 \mathrm{C}$ $\mathrm{SiC}$ which had been subjected to Potassium Hydroxide (KOH) wet etching and reactive ion etching (RIE) using tetrafluoromethane $\left(\mathrm{CF}_{4}\right)$. The Chinese Hamster Ovary (CHO) cells were directly cultured onto the prepared samples of $3 \mathrm{C}$ $\mathrm{SiC}, \mathrm{Si}$ and controls to investigate $3 \mathrm{C}-\mathrm{SiC}$ biocompatibility. The cells were detached from the substrates and grown further in 6 well plates for another 24 hours at $37^{\circ} \mathrm{C}$ with $5 \% \mathrm{CO}_{2}$ and $95 \%$ relative humidity for further testing. Cell viability percentage was determined by Trypan Blue exclusion technique which revealed the preference of the cells to grow and to proliferate on the treated $\mathrm{SiC}$ samples. However, the results could be inaccurate due to the nature of the testing which compromises the further ability of the cells to proliferate. Thus, a comparison was made by using Methylthiazolyldiphenyltetrazolium bromide (MTT) assay, a typical cytotoxicity assay, and also PrestoBlue ${ }^{\mathrm{TM}}$ reagent (which is the state-of-the-art assay for biocompatibility determination) to confirm the cell viability on the treated and untreated $\mathrm{SiC}$. Thus, the results showed that the cells proliferated better on surface of the $3 \mathrm{C}$ $\mathrm{SiC}$ treated with halogenated plasma which indicate the enhancement of biocompatibility of the semiconductor material due to the RIE.
\end{abstract}

\section{INTRODUCTION}

Microelectromechanical (MEMS) devices with high biocompatibility can be used for new and effective medical devices in human disease prevention and detection systems. The best condition for human physiological measurements is to avoid disruption of a patient's normal activity and this can

N. F. Mohd Nasir is with Biomedical Electronic Engineering, Universiti Malaysia Perlis, 02600 Arau, Perlis, Malaysia (phone: +604-988-5173; fax: +604-988-5167; e-mail: nashrul@unimap.edu.my).

E. Gan is with Vocational Health and Sciences, RMIT University, Bundoora, Australia (e-mail: emily.gan@rmit.edu.au).

R. Shukla is with School of Applied Science, RMIT University, Bundoora, Australia (e-mail: ravi.shukla@rmit.edu.au).

T. Istivan is with School of Applied Science, RMIT University, Bundoora, Australia (e-mail: taghrid.istivan@rmit.edu.au).

E. Pirogova is with School of Electrical and Computer Engineering, RMIT University, Melbourne, Australia (e-mail: elena.pirogova@rmit.edu.au).

P. Tanner is with Queensland Micro and Nanotechnology Center, Griffith University, Brisbane, Australia (e-mail: p.tanner@griffith.edu.au).

A.S. Holland is with School of Electrical and Computer Engineering, RMIT University, Melbourne, Australia (e-mail: anthony.holland@rmit.edu.au). be achieved by implantable biomedical microdevices [1]. Apart from the electronic design and fabrication issues, the material that should be chosen for these types of applications should firstly be shown to be biocompatible and ideally be suitable for use in conventional Silicon (Si) microfabrication technology $[2,3]$.

$\mathrm{SiC}$ is also currently getting significant attention as a biomedical material of interest. Vigorous biocompatibility studies were performed on the devices fabricated from hexagonal crystal variants of $\mathrm{SiC}$, either $6 \mathrm{H}-\mathrm{SiC}$ or $4 \mathrm{H}-\mathrm{SiC}$ [4-7]. For example, the application of amorphous $\mathrm{SiC}(\mathrm{a}-\mathrm{SiC})$ as a coronary stent coating shows contrary findings [8-10]. a$\mathrm{SiC}$ was found to reduce coronary events in patients, but, in another study, restenosis was shown in both patients implanted with bare stents and $\mathrm{SiC}$ coated stents after 6 months of surgery $[9,10]$. This proposes a further investigation on the biocompatibility and suitability of $\mathrm{SiC}$ as a material for implants.

Biocompatibility could be investigated by using assays commonly used in life science studies such as Trypan Blue exclusion assay, MTT assay and PrestoBlue assay. Trypan Blue determines cell viability by utilizing the ability of living cell membranes to exclude Trypan Blue dye, as opposed to a dead cell which has no such ability [11].

Yellow tetrazolium salt 3-(4, 5-dimethylthiazol-2-yl)-2, 5-diphenyltetrazolium bromide (MTT) (Invitrogen) assay is a conventional assay that is widely used to detect cell viability and cell cytotoxicity on the basis of detecting the conversion of yellow tetrazolium salt of the reagent by the viable cell into insoluble purple formazan [12-15]. In order to solubilize the formazan, dimethyl sulfoxide (DMSO) or isopropan-2-ol (IPA) is added to determine the absorbance of the solutions spectrophotometrically $[12,13]$. PrestoBlueTM reagent is a resazurin based solution used to quantitatively measure cell viability by determining the level of cellular metabolic activity of living cells [16-18]. It is a state-of-the-art cell viability reagent which has less protocol, much rapid than MTT assay and the most important aspect, it has limited side effect on the tested cells [19]. PrestoBlueTM is a new type of cell viability assay, which has been introduced recently for cell viability quantitative measurement.

Related studies on the effect of the fabrication process in semiconductor such as potassium hydroxide $(\mathrm{KOH})$ etching of silicon substrate and reactive ion etching (RIE) on the biocompatibility of $\mathrm{AlGaN} / \mathrm{GaN}$ [20] and polyimide [21] have been reported. The authors of these studies concluded that these processes posed little effect on the materials biocompatibility and cytotoxicity. Thus, the effect of typical micromachining steps used in semiconductor 
devices fabrication on cell viability nature of $3 \mathrm{C}-\mathrm{SiC}$ is established and included in this study.

\section{MATERIALS AND METHODS}

\section{A. Sample Preparations}

A layer of n-type 3C-SiC were grown epitaxially on 650 $\mu \mathrm{m}$ thick, $<100>\mathrm{Si}$ substrates by chemical vapor deposition (CVD) as described by Wang et al. [22]. The preparation of the $3 \mathrm{C}-\mathrm{SiC}$ samples using reactive ion etching of $3 \mathrm{C}-\mathrm{SiC}$ using $\mathrm{CF}_{4}$ gas and wet etching of $\mathrm{Si}$ using $\mathrm{KOH}$ up were described elsewhere by the authors [23, 24]. Si chip was used as a comparison. For control, the rectangular Thermanox $^{\mathrm{TM}}$ coverslips (pretreated for tissue culture application) as positive control and for the negative control, the coverslips were treated with Bovine Serum Albumin (BSA) was prepared.

Before any treatment, all the samples were rinsed with acetone, IPA and deionized (DI) water and later dipped in hydrofluoric (HF) acid for 30 seconds to remove natural oxide. $\mathrm{Si}$ and $3 \mathrm{C}$-SiC samples were diced into $10.5 \mathrm{~mm}$ $\times 22 \mathrm{~mm}$ similar to Thermanox ${ }^{\mathrm{TM}}$ coverslips shape and size. The samples were then sterilized by double autoclaved $\left(121^{\circ} \mathrm{C}\right)$ and treated with ultraviolet light (UV) radiation for 15-20 minutes prior to work.

\section{B. Cell Culture and Trypan Blue Exclusion Technique}

The Chinese Hamster Ovary (CHO) cells were subcultured on the sample materials (Thermanox ${ }^{\mathrm{TM}}$ slips, $\mathrm{Si}$ and $3 \mathrm{C}$-SiC) placed in 6 well cell culture plates (Greiner, \# 657 185). Approximately $2 \mathrm{ml}$ of stock solution of media (Dulbecco's Modified Eagle Medium (Gibcoß)) together with $1.0 \times 10^{5}$ cells $/ \mathrm{ml}$ were seeded to each well containing the materials. The seeded cell culture plates were then incubated at $37^{\circ} \mathrm{C}$ and $5 \% \mathrm{CO}_{2}$ overnight.

After incubation, the cells viability was observed using optical microscope prior to the quantitative testing. The cells from each well with different materials were trypsinized $(100 \mu \mathrm{l})$ for detachment and later were subcultured in 6 well plates for overnight. The cells growth and proliferation were observed by optical microscopy. The live cells were counted to determine their viability after detachment from the materials by staining the cells with Trypan Blue dye. Subsequently the $\mathrm{CHO}$ cells were counted using Countess ${ }^{\circledR}$ Automated Cell Counter (Invitrogen). Here, the cell viability percentage could be determined. These cells were cultured later for 24 hours to measure their viability using MTT (Invitrogen) assay and PrestoBlue ${ }^{\mathrm{TM}}$ Cell Viability reagent (Invitrogen, USA) assay. In these cell viability studies, 100 $\mu \mathrm{l}$ of solution consisted of media and antibiotics (Penicillin/ Streptomycin) (Invitrogen) with approximately $1.0 \times 10^{3}$ $\mathrm{CHO}$ cells cultured earlier were seeded to the wells of 96 well cell culture plates (Greiner, \# 655 180) and incubated at $37^{\circ} \mathrm{C}$ and $5 \% \mathrm{CO}_{2}$ overnight. Two 96 well culture plates were prepared for MTT assay test and PrestoBlue ${ }^{\mathrm{TM}}$ Cell Viability reagent (Invitrogen, USA) test.

\section{MTT Assay}

The plated cells were added with $20 \mu$ l of MTT assay. The plate was covered with the aluminum foil to protect MTT from light and it was agitated with the plate shaker for 5 minutes to ensure the MTT mixed uniformly with the cells mixture. Subsequently, it was incubated for 4 hours at $37^{\circ} \mathrm{C}$ and $5 \% \mathrm{CO}_{2}$ and later, $25 \mu \mathrm{l}$ of the mixtures were removed from the plated cells. Insoluble purple formazan were formed and then dissolved by adding $50 \mu \mathrm{l}$ of DMSO on each plated cell.

After that cells were incubated at $37^{\circ} \mathrm{C}$ and $5 \% \mathrm{CO}_{2}$ for 10 minutes. Experiments were performed in triplicates with each experiment repeated three times.

Cellular viability can be measured by:

$\frac{\left(O D_{595} \text { Sample- } O D_{595} \text { Background }\right)}{\left(O D_{595} \text { Control Sample- OD } D_{595} \text { Background }\right)} \times 100$

\section{PrestoBlue ${ }^{T M}$ Reagent Test}

PrestoBlue $^{\mathrm{TM}}$ Cell Viability reagent (Invitrogen, USA) assay $(10 \mu \mathrm{l})$ as supplied were added to the mixture and uniformly mixed by using the plate shaker for 5 minutes. The plate was incubated for 2 hours at $37^{\circ} \mathrm{C}$ and $5 \% \mathrm{CO}_{2}$ before measuring the absorbance at $595 \mathrm{~nm}$. Each experiment was made in triplicates and the experiments were repeated three times. Cellular viability was measured by expression (1).

\section{RESULT AND DISCUSSION}

\section{A. Trypan Blue Exclusion Technique}

Trypan Blue stain exclusion technique is a very powerful tool since it is not only able to provide information on the amount of cells (living or dead) but also capable in providing preliminary result about cell viability. Here, the cell viability percentage is assessed indirectly based on the CHO cell membrane integrity [25].

The cell viability result (Fig. 1) shows the highest percentage of viable cell was from the RIE and $\mathrm{KOH}$ treated 3C-SiC/Si samples and the untreated 3C-SiC/Si samples. All the $3 \mathrm{C}-\mathrm{SiC} / \mathrm{Si}$ based samples showed a higher cell viability (in percentage) compared to Si samples.

The highest percentage of cell viability is for the $\mathrm{KOH}$ and RIE treated samples which is approximately $88 \%$. This is due to the high ratio of the amount of the living cells to the total cells of the RIE and $\mathrm{KOH}$ treated 3C-SiC samples and the difference of this ratio is only about $10 \%$. 
Meanwhile, the differences for other samples (for the positive control, negative control, $\mathrm{Si}$, untreated $3 \mathrm{C}-\mathrm{SiC}$ and $\mathrm{KOH}$ only treated samples) ranges from $25-33 \%$ which explained lower cell viability percentage obtained for these samples.

Although this technique is able to measure cell membranes integrity but on the other hand, this technique compromised the ability of cells to continue their proliferation [25]. Thus, other types of assays capable of measuring cell viability are required for accurate verification the cell viability on the materials of interest.

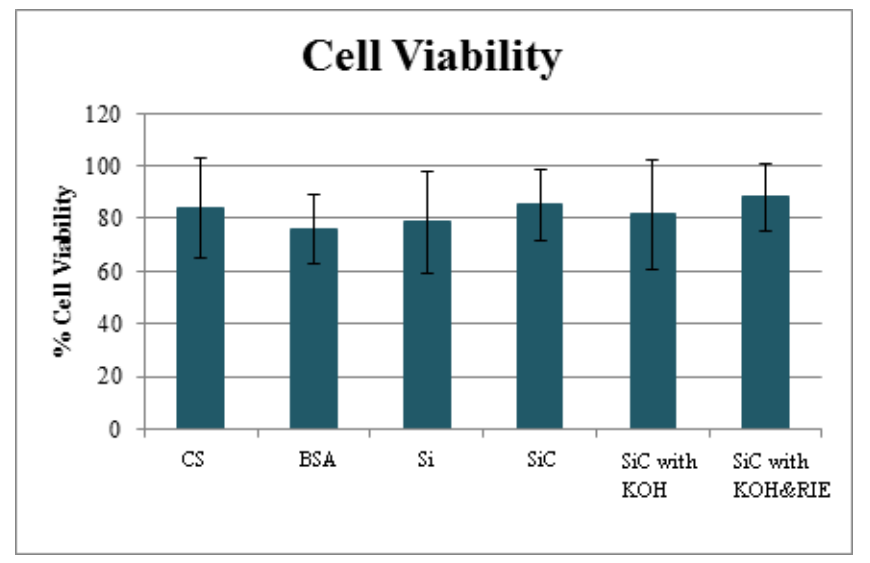

Figure 1. The cell viability percentage was obtained using Countess ${ }^{\circledR}$ Automated Cell Counter (Invitrogen) after stained by Trypan Blue dye.

\section{B. MTT Assay}

$\mathrm{KOH}$ treated $3 \mathrm{C}-\mathrm{SiC} / \mathrm{Si}$ and $\mathrm{RIE}$ and $\mathrm{KOH}$ treated $3 \mathrm{C}$ $\mathrm{SiC} / \mathrm{Si}$ in comparison to the positive control is expressed in mean \pm standard deviation. Here, the result for the RIE and $\mathrm{KOH}$ treated $3 \mathrm{C}-\mathrm{SiC} / \mathrm{Si}$ samples are in agreement with the result presented in the previous section where $\mathrm{CHO}$ cells showed higher viability level on the plasma etched and $\mathrm{KOH}$ treated 3C-SiC/Si samples which is approximately $91 \%$.

Viability percentage of $\mathrm{CHO}$ cells on both $\mathrm{Si}$ and negative control are better using MTT assay viability test (which are approximately 91\%) in comparison to untreated 3C-SiC and $\mathrm{KOH}$ treated 3C-SiC (which are $85 \%$ and $80 \%$ ). These results from $\mathrm{MTT}$ assay (for negative control, $\mathrm{Si}$, untreated $3 \mathrm{C}-\mathrm{SiC}$ and $\mathrm{KOH}$ only treated samples) contradicted with the Trypan Blue exclusion assay results. This contradiction is not surprising since, MTT assay, despite known as convenient and economic [4], but sometimes provides confusing and inaccurate result [26]. This is indicated in Fig. 2 by high standard deviation error bars where non-living cells are also able to reduce tetrazolium salt into soluble formazan [27]. Thus, as precaution, an extra care is needed while using this assay. In this case, these contradicting results should be accompanied and verified by another independent cell viability assay.

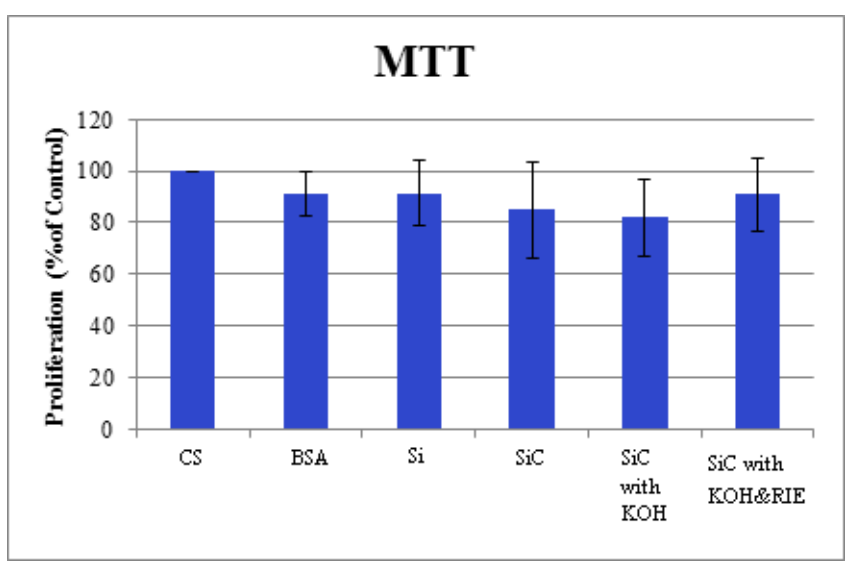

Figure 2. CHO cells viability percentage on the materials against control using MTT assay (Invitrogen, USA) assay.

\section{C. $\quad$ PrestoBlue ${ }^{T M}$ Reagent Test}

The result here has confirmed the positive effect of RIE on $3 \mathrm{C}-\mathrm{SiC}$. However, PrestoBlue ${ }^{\mathrm{TM}}$ indicates that $\mathrm{KOH}$ treated $3 \mathrm{C}-\mathrm{SiC} / \mathrm{Si}$ samples were also favored by the cells to rapidly grow. $\mathrm{CHO}$ cells were more viable on these types of samples. Therefore, it can be suggested that surface treatment of $\mathrm{SiC}$ surface might positively altered for a better cell growth or at least not to be toxic and thus, biocompatible.

As can be seen from Fig. 3, untreated 3C-SiC showed a proliferation rate similar to $\mathrm{Si}$ and the negative control. The results obtained were also relatively more reproducible in comparison to the MTT assay based on the small standard deviation error, which indicates the higher accuracy of the used reagent that supports the claim by Newman et al. [19].

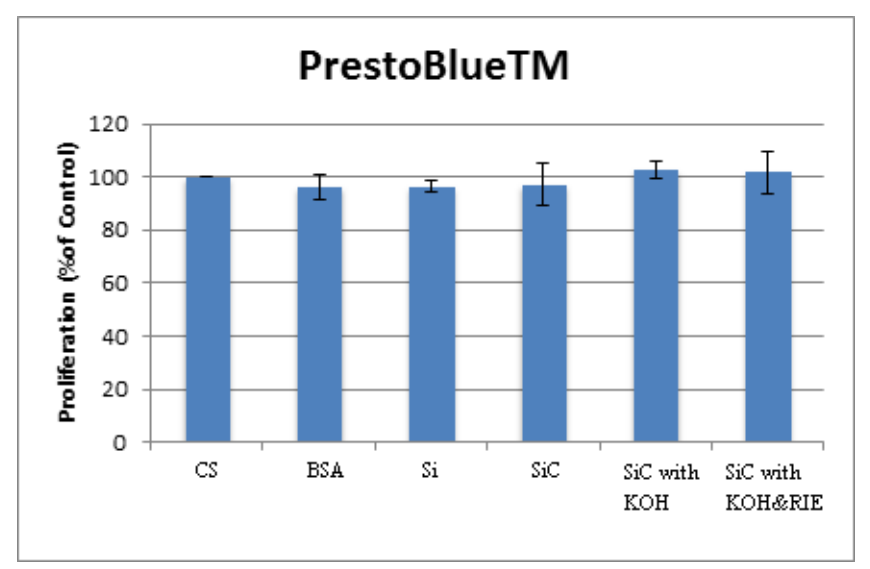

Figure 3. CHO cells viability percentage on the materials against control using PrestoBlue ${ }^{\mathrm{TM}}$ Cell Viability reagent (Invitrogen, USA) assay.

From here, in most results, 3C-SiC has better biocompatibility quality in comparison to $\mathrm{Si}$. This reaffirmed 
the biocompatibility of $\mathrm{SiC}$ against $\mathrm{Si}$ in literatures $[6,13,28,29]$. Chemical treatment such as immersing $3 \mathrm{C}-\mathrm{SiC}$ in $\mathrm{KOH}$ or $\mathrm{HF}$ solution did not alter 3C-SiC biocompatibility. This case was different with plasma treated 3C-SiC. The alteration of 3C-SiC surface had showed impact on its biocompatibility. Thus, based on the viability tests, plasma treatment of the $3 \mathrm{C}-\mathrm{SiC}$ surface had improved the biocompatibility quality of $3 \mathrm{C}-\mathrm{SiC}$. Plasma treatment might deposited C-rich layer on the 3C-SiC surface [30] and it is suggested carbon as a biomedical material showed good electrochemical potential comparable to living cells which lead to better quality of cell attachment [31].

\section{CONCLUSION}

The assessment and comparison of the analyzed samples such as: $\mathrm{Si}$, untreated $3 \mathrm{C}-\mathrm{SiC} / \mathrm{Si}, \mathrm{KOH}$ treated $3 \mathrm{C}-\mathrm{SiC} / \mathrm{Si}$ and $\mathrm{RIE}$ and $\mathrm{KOH}$ treated $3 \mathrm{C}-\mathrm{SiC} / \mathrm{Si}$ of their biocompatibility characteristics has reveals important discoveries in this subject. The CHO cells viability was chemically assessed using Trypan Blue exclusion assay, MTT assay and PrestoBlue ${ }^{\mathrm{TM}}$ reagents. The quantification of both total and living cells showed interesting results where cell counts for untreated and $\mathrm{KOH}$ treated $3 \mathrm{C}-\mathrm{SiC} / \mathrm{Si}$ samples were much higher than the positive control. Two viability tests were conducted to further verify the results. The viability of the cells previously cultured on RIE and $\mathrm{KOH}$ treated $3 \mathrm{C}-\mathrm{SiC} / \mathrm{Si}$ was high in both tests. However, lower results were obtained with MTT assay for untreated and $\mathrm{KOH}$ treated $3 \mathrm{C}-\mathrm{SiC}$, but this discrepancy can be attributed to the accuracy of the assay. $\mathrm{KOH}$ treated $3 \mathrm{C}-\mathrm{SiC}$ also showed high cell viability with PrestoBlue ${ }^{\mathrm{TM}}$ test. Here as a final conclusion statement, treating $3 \mathrm{C}-\mathrm{SiC}$ with plasma gasses such $\mathrm{CF}_{4}$ would improve the biocompatibility of $3 \mathrm{C}$ $\mathrm{SiC}$.

\section{ACKNOWLEDGMENT}

The authors would like to thank Mr. Eltaher Elshagmani and Mrs. Layla Mehdi Alhasan for their assistance in performing the cell culture in the School of Applied Science, RMIT University. The authors are also grateful to the support given by the Biomedical Electronic Engineering Programme and the School of Mechatronic Engineering, Universiti Malaysia Perlis for all the support given.

\section{REFERENCES}

[1] B. D. P. Ee Lim Tan , Brock Horton, Ranyuan Shao, Mohammed Zourob and Keat Ghee Ong "Implantable Biosensors for Real-time Strain and Pressure Monitoring," Sensors, vol. 8, pp. 6396-6406, 2008 .
[2] C. Hierold, B. Clasbrumme, D. Behrend, T. Scheiter, M. Steger, K. Oppermann, H. Kapels, E. Landgraf, D. Wenzel, and D. Etuodt, "Implantable low power integrated pressure sensor system for minimal invasive telemetric patient monitoring," in Micro Electro Mechanical Systems, 1998. MEMS 98. Proceedings., The Eleventh Annual International Workshop on, 1998, pp. 568-573.

[3] C. A. Zorman, "Silicon carbide as a material for biomedical microsystems," in Design, Test, Integration \& Packaging of MEMS/MOEMS, 2009. MEMS/MOEMS '09. Symposium on, 2009, pp. $1-7$.

[4] A. J. Rosenbloom, D. M. Sipe, Y. Shishkin, Y. Ke, R. P. Devaty, and W. J. Choyke, "Nanoporous SiC: A candidate semi-permeable material for biomedical applications," Biomedical Microdevices, vol. 6, pp. 261-267, 2004.

[5] R. Gómez, A. Ivorra, R. Villa, P. Godignon, J. Millán, I. Erill, A. Solà, G. Hotter, and L. Palacios, "A SiC microdevice for the minimally invasive monitoring of ischemia in living tissues," Biomedical Microdevices, vol. 8, pp. 43-49, 2006.

[6] G. Gabriel, I. Erill, J. Caro, R. Gómez, D. Riera, R. Villa, and P. Godignon, "Manufacturing and full characterization of silicon carbidebased multi-sensor micro-probes for biomedical applications," Microelectronics Journal, vol. 38, pp. 406-415, 2007.

[7] C. Iliescu, B. Chen, D. P. Poenar, and Y. Y. Lee, "PECVD amorphous silicon carbide membranes for cell culturing," Sensors and Actuators, B: Chemical, vol. 129, pp. 404-411, 2008.

[8] G. Mani, M. D. Feldman, D. Patel, and C. M. Agrawal, "Coronary stents: A materials perspective," Biomaterials, vol. 28, pp. 1689-1710, 2007.

[9] U. Kalnins, A. Erglis, I. Dinne, I. Kumsars, and S. Jegere, "Clinical outcomes of silicon carbide coated stents in patients with coronary artery disease," Medical Science Monitor, vol. 8, pp. PI16-PI20, 20026.

[10] L. F. L. Tanajura, J. E. M. R. Sousa, A. G. M. R. Sousa, A. Abizaid, J. E. T. Paula, M. Albertal, F. Feres, L. A. P. Mattos, R. Staico, and I. M. F. Pinto, "Estudo prospectivo e randomizado de pacientes tratados com e sem stents revestidos com carbeto de silício amorfo para a prevenção da reestenose coronariana. Avaliação ultra-sonográfica," Arquivos Brasileiros de Cardiologia, vol. 83, pp. 59-63, 2004.

[11] W. Strober, "Trypan Blue Exclusion Test of Cell Viability," in Current Protocols in Immunology, ed: John Wiley \& Sons, Inc., 2001.

[12] J. M. Edmondson, L. S. Armstrong, and A. O. Martinez, "A rapid and simple MTT-based spectrophotometric assay for determining drug sensitivity in monolayer cultures," Methods in Cell Science, vol. 11, pp. 15-17, 1988.

[13] C. Coletti, M. J. Jaroszeski, A. M. Hoff, and S. E. Saddow, "Culture of mammalian cells on single crystal SiC substrates," 2006, pp. 46-51.

[14] N. J. Marshall, C. J. Goodwin, and S. J. Holt, "A critical assessment of the use of microculture tetrazolium assays to measure cell growth and function," Growth Regulation, vol. 5, pp. 69-84, 1995.

[15] T. Mosmann, "Rapid colorimetric assay for cellular growth and survival: Application to proliferation and cytotoxicity assays," Journal of Immunological Methods, vol. 65, pp. 55-63, 1983.

[16] A. C. Reisetter, L. V. Stebounova, J. Baltrusaitis, L. Powers, A. Gupta, V. H. Grassian, and M. M. Monick, "Induction of inflammasome-dependent pyroptosis by carbon black nanoparticles," Journal of Biological Chemistry, vol. 286, pp. 21844-21852, 2011.

[17] R. J. Tynan, J. Weidenhofer, M. Hinwood, M. J. Cairns, T. A. Day, and F. R. Walker, "A comparative examination of the antiinflammatory effects of SSRI and SNRI antidepressants on LPS stimulated microglia," Brain, Behavior, and Immunity, vol. 26, pp. 469-479, 2012.

[18] T. Machleidt, M. B. Robers, S. B. Hermanson, J. M. Dudek, and K. $\mathrm{Bi}$, "TR-FRET Cellular Assays for Interrogating Posttranslational Modifications of Histone H3," Journal of Biomolecular Screening, vol. 16, pp. 1236-1246, December 1, 20112011.

[19] R. A. Newman, S. Gopinath, and D. Kuninger, "Multiplexing with PrestoBlue (TM) Reagent: Providing Accurate Viability Assessment of Primary Cells Following Treatment with Toxicological Compounds \& Enabling Downstream Functional Assays," In Vitro Cellular \& Developmental Biology-Animal, vol. 47, pp. S32-S33, Jun 2011.

[20] I. Cimalla, F. Will, K. Tonisch, M. Niebelschütz, V. Cimalla, V. Lebedev, G. Kittler, M. Himmerlich, S. Krischok, J. A. Schaefer, M. Gebinoga, A. Schober, T. Friedrich, and O. Ambacher, "AlGaN/GaN 
biosensor-effect of device processing steps on the surface properties and biocompatibility," Sensors and Actuators B: Chemical, vol. 123, pp. 740-748, 2007.

[21] T. Doerge, S. Kammer, M. Hanauer, A. Sossalla, and S. Steltenkamp, "Novel method for a flexible double sided microelectrode fabrication process," 2009.

[22] L. Wang, S. Dimitrijev, J. Han, A. Iacopi, L. Hold, P. Tanner, and H. B. Harrison, "Growth of $3 \mathrm{C}-\mathrm{SiC}$ on $150-\mathrm{mm} \mathrm{Si}(100)$ substrates by alternating supply epitaxy at $1000{ }^{\circ}$ c," Thin Solid Films, vol. 519, pp. 6443-6446, 2011.

[23] N.F. Mohd Nasir, C.M. Shah, P.W. Leech, G.K. Reeves, E. Pirogova, T. Istivan, P. Tanner and A.S. Holland. "Fabrication of 3C-Silicon Carbide Membranes: Towards Development of Novel Microdevices for Biomedical Applications". 2012 International Conference on Biomedical Engineering (ICoBE 2012) Proceedings, pp. 589-593, 2012.

[24] N. F. Mohd Nasir, A. S. Holland, G. K. Reeves, P. W. Leech, A. Collins, and P. Tanner, "Specific contact resistance of ohmic contacts to n-type SiC membranes," in MRS Spring Meeting, San Francisco, CA, 2012, pp. 99-104.

[25] N. H. Masoodzadehgan, "Superparamagnetic iron oxide nanoparticles development, characterization, cupper-64 labeling and cellular tracking," Master of Science in Medical Physics, Department of Biomedical Engineering, Georgia Institute of Technology, Georgia, USA, 2012.

[26] H. Wan, R. Williams, P. Doherty, and D. F. Williams, "A study of the reproducibility of the MTT test," Journal of Materials Science: Materials in Medicine, vol. 5, pp. 154-159, 1994.

[27] M. Pagé, N. Bejaoui, B. Cinq-Mars, and P. Lemieux, "Optimization of the tetrazolium-based colorimetric assay for the measurement of cell number and cytotoxicity," International Journal of Immunopharmacology, vol. 10, pp. 785-793, 1988.

[28] C. L. Frewin, C. Locke, S. E. Saddow, and E. J. Weeber, "Singlecrystal cubic silicon carbide: An in vivo biocompatible semiconductor for brain machine interface devices," in Engineering in Medicine and Biology Society,EMBC, 2011 Annual International Conference of the IEEE, 2011, pp. 2957-2960.

[29] C. Coletti, M. J. Jaroszeski, A. Pallaoro, A. M. Hoff, S. Iannotta, and S. E. Saddow, "Biocompatibility and wettability of crystalline $\mathrm{SiC}$ and Si surfaces," Lyon, 2007, pp. 5849-5852.

[30] J. W. Palmour, R. F. Davis, T. M. Wallett, and K. B. Bhasin, "Dry etching of b-SiC in $\mathrm{CF}_{4}$ and $\mathrm{CF}_{4}+\mathrm{O}_{2}$ mixtures," Journal of Vacuum Science \& Technology A: Vacuum, Surfaces, and Films, vol. 4, pp. 590-593, 1986.

[31] A. Angelescu, I. Kleps, M. Mihaela, M. Simion, T. Neghina, S. Petrescu, N. Moldovan, C. Paduraru, and A. Raducanu, "Porous silicon matrix for applications in biology," Reviews on Advanced Materials Science, vol. 5, pp. 440-449, 2003 